\title{
АНТИБАКТЕРІЙНА СТІЙКІСТЬ ЕЛЕКТРОЗВАРНОГО З'ЕДНАННЯ ЖИВИХ ТКАНИН
}

С. С. Подпрятов ${ }^{1,2}$, С. Г. Гичка², І. М. Слободянюк ${ }^{2}$, О. І. Уманець ${ }^{3}$, В. А. Ткаченко ${ }^{4}$, С. М. Корбут ${ }^{2}$, В. В. Салата ${ }^{1,2}$, В. В. Іваха ${ }^{1,2}$, І. О. Бєлоусов ${ }^{1,2}$, В. П. Корчак ${ }^{2}$, В. В. Щепетов ${ }^{1}$, О. В. Сидоренко О. Ф. Петренко ${ }^{5}$ Д. В. Тарнавський ${ }^{5}$

${ }^{1}$ Київський центр електрозварювальної хірургії та новітніх технологій,

${ }^{2}$ Київська міська клінічна лікарня № 1 ,

${ }^{3}$ Головний військово-медичний клінічний центр «ГВКГ»,

${ }^{4}$ Інститут електрозварювання імені $Є$. О. Патона НАН України,

${ }^{5}$ Національний університет біоресурсів і природокористування України, м. Київ

\section{ANTIBACTERIAL RESISTANCE OF ELECTRIC WELDING CONNECTION OF LIVING TISSUES}

\author{
S. S. Podpryatovi,2, S. G. Gychka², I. M. Slobodyanyuk², O. I. Umanets ${ }^{3}$, V. A. Tkachenko4, \\ S. M. Korbut ${ }^{2}$, V. V. Salata ${ }^{1,2}$, V. V. Ivakha ${ }^{1,2}$, I. O. Belousov' ${ }^{1,2}$, V. P. Korchak ${ }^{2}$, V. V. Shchepetov', \\ O. V. Sydorenko', O. F. Petrenko ${ }^{5}$, D. V. Tarnavskyi ${ }^{5}$ \\ 'Kyiv Centre of Electric Welding Surgery and Modern Technologies, \\ ${ }^{2}$ Kyiv Municipal Clinical Hospital No 1, \\ ${ }^{3}$ Main Military-Medical Clinical Centre «MMMCC», \\ ${ }^{4}$ Paton Institute of Electric Welding, Kyiv \\ ${ }^{5}$ National University of Bioresources and the Nature Exploitation of Ukraine, Kyiv
}

\begin{abstract}
Рефрерат
Матеріали і методи. Антибактерійна стійкість електрозварного з'єднання (ЕЗ) досліджена в умовах гнійно-некротичного ураження, бактеріального забруднення, параканкрозного запалення або наявності калу у міжкишковому анастомозі (МКА), в судинах діаметром до 10 мм, міхуровій протоці діаметром до 12 мм, анальній нориці діаметром до 5 мм. В експерименті на 17 свинях, маса тіла 45 - 75 кг, та в клініці у 74 хворих віком від 24 до 72 років використовували апарати ЕК-300М1 і ЕКВ3-300 ПатонмедТМ. Результати. У строки спостереження до 30 діб неспроможність ЕЗ у відкритій рані, черевній порожнині, відхіднику не спостерігали. Виявлені E. coli (3 штами), E. faecalis, E. cloacae, C. hofmanii, S. aureus в концентрації до $10^{8}$, патогенні штами Clostridium у 3 хворих. Відзначене утворення цілісної структури біологічної тканини по всій лінії створення ЕЗ. Вже на 4-ту добу в МКА виявляли новоутворену грануляційну тканину з судинами, продуктивне запалення.

Висновки. ЕЗ є суцільним, зберігає просторову структуру залучених волокон, не містить вільних клітинних фрагментів, що $є$ тригерами запалення та поживними речовинами, забезпечує первинне загоєння у присутності мікроорганізмів з лізуючими властивостями.

Ключові слова: хірургія; електрозварювання; електрозварне з'єднання; антибактерійний кишковий анастомоз; мікроорганізми

Abstract

Materials and methods. Antibacterial resistance of electric welding connection (EC) was investigated in conditions of purulent-necrotic affection, bacterial spoilage, paracancrous inflammation or presence of faces in interintestinal anastomosis (IIA), in vessels up to $10 \mathrm{~mm}$ in diameter, in cystic duct - up to $12 \mathrm{~mm}$ in diameter, and anal fistula up to $5 \mathrm{~mm}$ in diameter. In experiment on 17 pigs, the body mass $45-75 \mathrm{~kg}$, and in the clinic in 74 patients ageing 24- $72 \mathrm{yrs}$, the apparatuses EK-300M1 and EKB3-300 Patonmed were used.

Results. In terms of follow-up during 30 days insufficiency of EC in open wound, abdominal cavity, anus were not observed. There were revealed E. coli (3 strains), E. faecalis, E. cloacae, C. hofmanii, S. aureus in concentration up to $10^{8}$, pathogenic strains of Clostridium in 3 patients. Development of integrative structure of biological tissue along all the line of the EC creation was noted. Already on the fourth day in IIA a newly created granulation tissue with vessels, productive inflammation were revealed.

Conclusion. EC constitutes one mass, preserves a space structure of filaments involved, do not contain free cellular fragments, which constitute the trigger of inflammation and nutrient substances, guarantees primary healing in presence of microorganisms, owing leasing properties.

Keywords: surgery; electric welding; electrowelding connection; antibacterial intestinal anastomosis; microorganisms.
\end{abstract}

В клінічних спостереженнях доведена ефективність електрозварювання живих тканин в умовах їх інфікування [1]. В зоні створеного МКА концентрація деяких мікроорганізмів збільшується на $1-2$ порядки [2]. В експериментальних дослідженнях МКА накладали без передопераційного очищення кишечнику.
Тим не менше, ускладнень загоєння електрозварного МКА, зумовлених впливом мікроорганізмів, не було [3]. Отже, ймовірно, властивості створеного Е3 в МКА визначають його антибактерійну стійкість.

Мета дослідження: вивчити антибактерійну стійкість Е3 судини, міхурової протоки, нориці та відрізків кишки в МКА в експерименті та клініці.

\section{МАТЕРІАЛИ I МЕТОДИ ДОСЛІДЖЕННЯ}

В умовах модельного експерименту та ветеринарної операційної створене Е3 у вигляді електрозварного МКА у 17 свиней породи 
„велика біла”, маса тіла 45 - 75 кг. Кишечник не очищували.

В клініці створене Е3 тканин та органних структур в умовах гнійно-некротичного ураження, бактеріального забруднення тканин, параканкрозного запалення або наявності вмісту товстої кишки. В період 2004 - 2016 рр. Е3 створене у 74 хворих віком від 24 до 72 років, 3 них 52 чоловіків та 22 жінок

Проведено біоетичну експертизу експериментальних та клінічних досліджень, вони схвалені Комітетом з біоетики Національного університету біоресурсів і природокористування України та Комітетом з етики Національної медичної академії післядипломної освіти імені П. Л. Шупика МОЗ України.

Для створення Е3 використовували електрозварювальні апарати ЕК-300M1 і ЕКВ3-300 Патонмед ${ }^{\mathrm{TM}}$ виробництва Інституту електрозварювання ім. Є. О. Патона, дозволені для клінічного використання. Відповідно до хірургічних та тканинних умов створення ЕЗ використовували спеціалізовані електрохірургічні інструменти: затискач без обмежувачів стискання, затискач з обмежувачами стискання, спеціалізований електрозварювальний інструмент для Е3 відрізків кишки в МКА виробництва Патонмед (Україна).

Перекривали судини діаметром від 2 до 10 мм шляхом створення Е3 ix стінок, після затискання між електродами на браншах відповідного затискача, з обмежувачем стискання (діаметр 4 мм і більше) або без такого. Подібним чином перекривали міхурову протоку діаметром 5-12 мм. Для перекриття просвіту анальних та аноректальних нориць діаметром від 1 до 5 мм їх стінки стискали між кінчиками електродів. При створенні Е3 у вигляді МКА кінець у кінець стискали відрізки кишки за допомогою спеціального інструмента в спосіб, аналогічний такому при використанні одномоментного циркулярного скобкового пристрою. Після стискання циркулярних електродів до складених відрізків кишки подавали електричну напругу у відповідному режимі, створюючи Е3.

Використовували переважно автоматичний режим створення Е3. Режим, в якому дозування електрозварного впливу контролював хірург, у вигляді основного режиму застосовували лише для судин невеликого діаметра.

Оцінювали цілісність і спроможність Е3 безпосередньо - за його розташування у відкритій рані, або опосередковано - за наявності надходження крові, вмісту кишечнику по дренажах, підведених до місця Е3, або норицевого ходу.

У модельному експерименті етапні дослідження здійснювали в строки, що відповідали певній фазі загоєння: через 1 добу (3 спостереження), 4 доби (3 спостереження), 7 діб (3 спостереження), 21 добу (4 спостереження), 45 діб (3 спостереження), 90 діб (1 спостереження). Тварин вводили у наркоз, здійснювали широку лапаротомію для повноцінного огляду черевної порожнини, за участі морфолога забирали МКА для морфологічних досліджень.

Для визначення збудників гнійного запалення в рані вміст кишки чи вогнища запалення вміщували на збагачувальне та спеціалізовані поживні середовища: Ендо, Симонса, Кліглера, кров'яний агар, жовтковосольовий агар, лактоагар, біфідум.

Морфологічні характеристики E3 досліджували у видалених тканинах $з$ частиною Е3. Первинну структуру Е3 досліджували під світловим мікроскопом 3 оптичним збільшенням $\times 400$, , $з$ імунофарбуванням колагенових та еластичних волокон, глікозаміногліканів, поліпептидів, ліпідів. Первинну структуру Е3 додатково досліджували під електронним мікроскопом.

Клінічні спостереження віддалених змін у зоні Е3 здійснювали 3 використанням колоноскопії, ультразвукового дослідження, допплерографії в строки від 1 до 12 міс після створення Е3.

\section{РЕЗУЛЬТАТИ \\ ТА ÏХ ОБГОВОРЕННЯ}

3 ділянок Е3 виділені аеробні мікроорганізми у концентрації, що відповідала такій у вмісті товстої кишки та/або при гострому гнійному запаленні. Виявлені E. coli (3 штами), E. faecalis, E. cloacae, C. hofmanii, S. aureus в концентрації $10^{8}$ - для провідного мікроорганізму, яким переважно була E. coli, та $10^{3}-10^{5}$ - для конкуруючого, переважно Е. faecalis або S. aureus. Патогенні шта- ми Clostridium виявлені у 3 спостереженнях.

У строки до 30 діб після операції ознак неспроможності Е3 не спостерігали. Кровотечі з перекритих в 3оні запалення судин як у черевній порожнині, так і відкритій рані при ампутації нижньої кінцівки, розкритті флегмони промежини чи парапроктиту не було. Не виявлені ознаки рецидиву нориці, перекритої у просвіті каналу відхідника, в тому числі на тлі гострого парапроктиту. Не спостерігали утворення жовчної нориці після електрозварювальної холецистектомії.

У МКА ознак неспроможності Е3 не було. Незважаючи на утворення в просвіті кишки виразки по лінії Е3 глибиною до межі підслизового прошарку і м'язової оболонки кишки, у черевній порожнині не спостерігали нашарувань фібрину, переміщення сальника до МКА, інших ознак неспроможності.

За даними морфологічного дослідження відзначали утворення під впливом дозованого електрозварного впливу цілісної структури біологічної тканини, суцільно-конгломератної (ЕК-300M1) або суцільно-волокнистої (ЕКВ3-300 Патонмед ${ }^{\mathrm{TM}}$ ), по всій лінії Е3, без зон обвуглення, крововиливу. При цьому в місці створення Е3 частково зберігалися ядра, повністю - ущільнені сполучнотканинні та еластичні волокна, без значних проміжків, що мали гомогенну структуру і зберігали просторові контури. Фрагментів клітин, живих мікроорганізмів в зоні Е3 не було (рис. 1).

Дном виразки в місці накладення електродів були вогнищево некротизовані структури (неглибокий некроз) стінки кишки (рис. 2).

Вже на 4-ту добу в дні виразки виявляли новоутворену грануляційну тканину з новоутвореними судинами, по краях слизової оболонки з'єднаних стінок кишки - виражену продуктивну запальну реакцію у вигляді щільного ексудативного набряку (рис. 3). При цьому зміщення сальника, ознак перитоніту не було.

Отже, навіть за відсутності бар'єру слизової оболонки й підслизового прошарку структура E3 непроникна для мікроорганізмів з просвіту кишки в ранньому післяопераційному періоді, переходить у фазу загоєння 


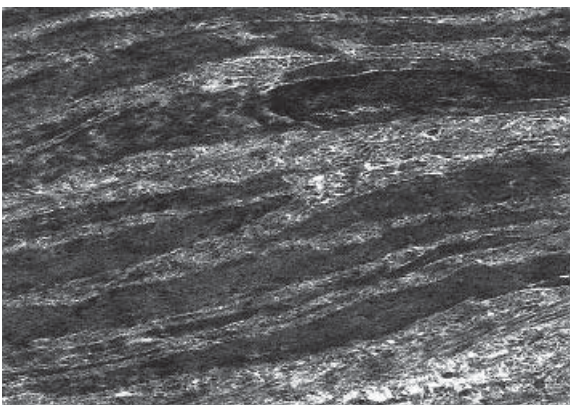

Рис. 1.

Електронограма

Зближення м'язових волокон, з'єднання 3 колагеновими волокнами.

Мікроорганізми не виявлені. 3б. х6000.

без ознак альтерації чи відторгнення.

Життездатність новоутвореної структури та іï первинну антибактерійну стійкість визначають: суцільність як власне E3, так і його межі 3 навколишніми тканинами, наявність збереженої просторової структури колагенових волокон в товщі Е3, утвореної за типом первинної полімеризації, а не дроблення.

У віддаленому періоді, за даними ультразвукового дослідження 3 допплерографією, спостерігали збереження цілісності Е3 в перекритих судинах, нориці, зміну ехоструктури навколишніх тканин без формування грубого рубця в зоні Е3.

За даними колоноскопії стенозування зони ЕЗ в МКА не виявлене. Зруйнована електродами слизова оболонка відновлювалася без ознак рубцевої деформації. Через 1 рік виявити зону Е3 в МКА не вдалося через однорідність структури кишки.

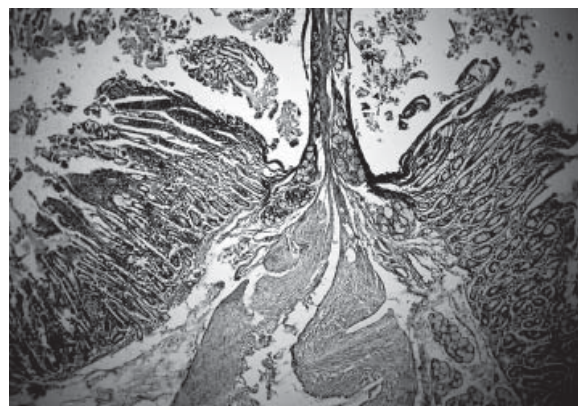

Рис. 2.

Мікрофото.

Ділянка МКА товстої кишки після створення Е3.

Деструкція слизової оболонки та підслизового прошарку на ділянці електрозварювання, збереження

структури стиснутої м'язової оболонки.

Тісний контакт м'язової оболонки.

Збереження просвіту кровоносних судин в стінці кишки поблизу зони Е3.

Забарвлення гематоксиліном та еозином. 3б. $x 50$.

\section{ВИсновки}

1. Структура ЕЗ від моменту створення $є$ суцільною як всередині, так і з навколишніми тканинами, зберігає просторову структуру залучених колагенових та еластичних волокон.

2. Структура Е3 не містить вільних клітинних фрагментів, що можуть бути пусковими механізмами для запалення та поживними речовинами для мікроорганізмів.

3. Відсутність грубої сполучної тканини в Е3 у віддаленому періоді підтверджує первинне загоєння.

4. Структура Е3 в судинах, міхуровій протоці, аноректальній нориці та відрізках кишки в МКА за наявності мікроорганізмів $з$ лізуючими

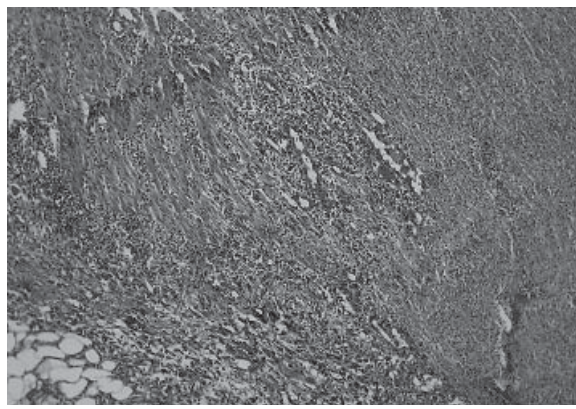

Рис. 3. Мікрофоото.

Ділянка МКА на 4-ту добу після створення Е3.

Збережені та просторово орієнтовані колагенові волокна підслизового прошарку стінки кишки в зоні ЕЗ.

Новоутворені волокна сполучної тканини пронизують зону лейкоцитарної інсрільтрації, поміж них новоутворені судини.

Мікроорганізми, окремі фрагменти фібрил не виявлені.

Забарвлення за ван-Гізон. 3б. х200.

властивостями без морфологічних та клінічних ознак руйнації впродовж 30 діб після операції.

\section{ЛITEPATYPA/REFERENCES}

1. Podpriatov SS, Korbut SM, Marynskyi HS, Tkachenko VA, Sydorenko OV. Novitni tekhnolohii v likuvanni paraproktytu. Visnyk Ukrainskoi medychnoi stomatolohichnoi akademii. 2007;13,1(41):222-4. [In Ukrainian].

2. Shogan BD, Smith DP, Christley S, Gilbert JA, Zaborina O, Alverdy JC. Intestinal anastomotic injury alters spatially defined microbiome composition and function. Microbiome. 2014;(2):35-45.
3. Paton BE, Ivanova ON, redaktory. Tkanesokhranyayushchaya vysokochastotnaya svarka v khirurgii. Atlas. Kiev: Naukova dumka; 2009. 200 s. [In Russian]. 